\title{
Determinants of Household Saving in Dire Dawa City, Eastern Ethiopia
}

\author{
Meron Hailu* Endrias Geta \\ School of Agricultural Economics and Agribusiness, Haramaya University; P.O. Box: 106, Haramaya, Ethiopia
}

\begin{abstract}
Household saving is a crucial determinant of the supply of funds for investment. However, saving trend in Ethiopia particularly in the study area is very low and little is known empirically about its patterns and determinants. This study, therefore, was aimed at investigating the determinants of the saving behavior of households in Dire Dawa city, Eastern Ethiopia. Data were collected from four Kebeles and 122 sample households taken from the selected kebeles by using interview schedule. Descriptive statistics and Tobit regression model were used to analyze the data. The results showed that $70.5 \%$ of the entire sample households had savings during the survey time. The results of Tobit model revealed that annual income of household head education level, credit use of the household, annual expenditure of the household, self-employed, location of business area and the perception of interest rate had significant influence on the amount of household saving in the study area. And also 57\% of the households used formal institution for saving. The findings suggest that saving of the households is largely determined by income level. It is therefore important to ensure the availability of credit service, create awareness and educate the households to enhance saving.
\end{abstract}

Keywords: saving, household saving, Dire Dawa

DOI: $10.7176 / \mathrm{JESD} / 11-21-05$

Publication date: November $30^{\text {th }} 2020$

\section{Introduction}

Saving is a key macroeconomic variable, as it is a potential source of investment and thus economic growth. It also plays a role in the monetary transmission mechanism. Usually, the private sector, including households, provides the bulk of savings in an economy. Households are heterogeneous in terms of size, economic activity, income, net wealth and cultural background. This means that investigating households' behavior at the aggregate level only by looking at the "average" household ignores many potentially important aspects. Therefore, in the recent years, several central banks have increasingly invested effort into exploring households' behavior and balance sheets at the individual, i.e., the micro level (Besley, 2005).

The Ethiopian rate of national saving particularly the individual saving is expected to be very low and this low level of national saving is expected to limit the expected rate of economic growth of the economy. According to Ministry of Finance and Economic Development (2010), one of the major challenges encountered in the past five years of PASDEP implementation is low level of domestic savings to support the huge demand of the country's investment for accelerating growth and development in the process of eradicating poverty. The national saving was $9 \%$ of GDP at the beginning of the growth and transformation plan in 2010/11. Because of the low level of saving, the national investment of the Ethiopia is dependent on foreign direct investment rather than domestic investment. Though, foreign direct investment has paramount importance on Ethiopian economic growth and development, its importance is less than the domestic investment.

\section{Review of Literature}

Households' saving represents the difference between their current income and their current consumption. By not spending some of their current income on consumption, or alternatively by borrowing, households can accumulate financial assets, such as deposits and shares, and housing assets. One of the serious problems confronting poor countries including Ethiopia is the savings and investment gap (Deaton, 2005; Rogg, 2006).

There some theoretical models in literature that state different determinate of saving. The Orthodox household saving theories, the permanent income hypothesis assumes a rational household that maximize utility through consumption decisions. Friedman (1957) postulated a household whose consumption at time depends on its permanent income. The Life-Cycle Hypothesis is based on the assumption that consumers set their lifetime patterns of consumption and saving so as to maximize utility subject to a lifetime budget constraint (Obwona, and Ssentamu 1996). The Neo-Keynesian growth models include a saving function which goes back to the classical economists. According to Marios B. (1998), there is a separation of households into wage earners, who consume all the income they receive, and entrepreneurs, who earn profits which are saved and re-invested.

As many of the researchers indicate that the behavior of saving in Ethiopia has an impact in the economic growth of rural areas. The results of the descriptive and economic analyses of the determinants of household savings shows that $79.2 \%$ of sample households practiced saving with the average amount of 11365.3 Birr. The significant determinant explanatory variables of rural household savings in the study area were household head 
education level, live stockholdings, access to credit service, income, investment, training participation, contact with extension contacts, forms of savings and saving motives (Girma et al., 2013). This study shows rural farm households indeed save in respective of their low economic status. However, as these households mainly use the informal saving institutions, their savings is hardly traced in the national account. Policy-wise, efforts should be made to encourage the rural households to save through trainings and using the formal channel.

\section{RESEARCH METHODOLOGIES}

\subsection{Background and sampling methods}

Dire Dawa Administration (DDA) comprises Dire Dawa city and the surrounding rural areas. It is divided into nine urban kebeles and 21 rural kebeles. Dire Dawa city, located in the eastern part of the country, has an estimated total land area of $39.54 \mathrm{Km}^{2}$. It is located at $515 \mathrm{Km}$ east of Addis Ababa between Addis Ababa and Djibouti. Its altitude is about 1200 meter above sea level. The total population of the DDA is projected to reach at 383,529 in July 2013, of which $192,095(50.1 \%)$ are male and 191,434 (49.9\%) are female. The majority of the population resides in urban areas, i.e., 283,773 (74\%) and the remaining 99,756 (26\%) lives in rural areas. Out of the total urban population of 283,773 , the males constitute $14,131(50.1 \%)$ whereas the remaining $14,663(49.9 \%)$ are females (CSA, 2007).

A two stage sampling technique was applied to generate the required primary data. In the first stage, the nine kebeles of Dire Dawa city were grouped into two according to their level of business activity. In reference with the corporation for the purpose of earning a profit and related to providing goods and services for the market, the one with high business activity included four kebeles and that with low business activity included five kebeles. Then randomly two kebeles were selected from high business activity group and two kebeles from low business activity group. In the second stage, 122 respondents were selected randomly from four kebeles using probability proportional to size sampling method.

\subsection{Model specification}

In order to achieve the second objective of the study i.e. to identify determinants of household level saving of the residents of Dire Dawa Tobit model was employed.

The saving amount was the dependent variable used for this study. To analyze determinants of household saving amount, Tobit model (Tobin, 1958) was used. The Tobit model specification is given as follows:

$$
\begin{array}{cc}
Y_{i}^{*}=X_{i} \beta+\mu_{i} \ldots \ldots \ldots \ldots \ldots \ldots \ldots \ldots \ldots \ldots \ldots \ldots \ldots \\
Y_{i}=Y_{i}^{*} & \text { if } Y_{i}^{*}>0 \\
=0 & \text { if } Y_{i}^{*} \leq 0
\end{array}
$$

Where: $Y_{i}$ is the observed amount of household savings (measured in birr).

$\mathrm{Y}_{\mathrm{i}}{ }^{*}$ is the latent variable which is not observed

$\beta$ is Vector of unknown parameters

$\mathrm{X}_{\mathrm{i}}$ is vector of independent variable affecting household savings.

The zero threshold value in the model is not a very restrictive assumption, because the threshold value can be set to zero or assumed to be any known or unknown value. The model parameters are estimated by maximizing the Tobit likelihood function of the following form (Maddala, 2005; Gujarati, 2007).

$$
\mathrm{L}=\prod_{Y_{i}^{*}} \frac{1}{\sigma} f\left(\frac{Y_{i-\beta_{i X_{i}}}}{\sigma}\right) \prod_{Y_{i}^{*} \leq 0} \mathrm{~F}\left(\frac{\beta_{i X_{i}}}{\sigma}\right)
$$

Where $\mathrm{f}$ and $\mathrm{F}$ are the density probability function and cumulative distribution function of $\mathrm{Yi}^{*}$, respectively. $\Pi_{Y}$ $<0$ means the saving over i for which $Y i^{*} \leq 0$, and $\Pi_{Y}>0$ means the saving over those $\mathrm{i}$ for which $Y i^{*}>0$.

Maximum likelihood estimation would use logarithmically transformed version of Equation (5). It may not be sensible to interpret the coefficients of a Tobit in the same way as one interprets coefficients in an uncensored linear model. Hence, one has to compute the derivatives of the estimated Tobit model to predict the effects of changes in the exogenous variables.

Greene (2003) proposed the following techniques to decompose the effects of explanatory variables into the probability and intensity effects of saving. Thus, a change in Xi (explanatory variables) has two effects. It affects the probability that the observation will fall in positive part of the distribution and it affects the conditional mean of $\mathrm{Yi}^{*}$ in the positive part of the distribution. This decomposition approach is used in this study. The Change in the probability of saving when the independent variable $\mathrm{X}_{\mathrm{i}}$ changes by one unit can be computed as:

$$
\frac{\partial F(z)}{\partial X_{i}}=f(z) \frac{\beta_{i}}{\sigma}
$$

The marginal effect of an explanatory variable on the expected value of the dependent variable is:

$$
\begin{aligned}
\frac{\partial E\left(Y_{i}\right)}{\partial X_{i}}= & \mathrm{f}(\mathrm{z}) \beta_{i} \\
& \text { Where, } \mathrm{Z}=\frac{\beta_{i X_{i}}}{\partial}
\end{aligned}
$$

The change in intensity of dependent variable with respect to a change in an explanatory variable among 
the savers :

$$
\frac{\partial E\left({ }^{Y_{i}} / Y_{i}^{*>0}\right)}{\partial X_{i}}=\beta_{i}\left[i-Z \frac{f(z)}{F(Z)}-\left(\frac{f(z)}{F(Z)}\right)^{2}\right]
$$

Whereas $\mathrm{F}(\mathrm{z})$ is the cumulative normal distribution of $\mathrm{Z}, f(\mathrm{z})$ is the value of the derivative of the normal curve at a given point (i.e., unit normal density), $\mathrm{Z}$ is the $\mathrm{z}$ score for the area under normal curve, $\mathrm{b}$ is a vector of Tobit maximum likelihood estimates and $\mathrm{s}$ is the standard error of the error term.

\section{RESULTS AND DISCUSSION}

\subsection{Descriptive Results}

\subsubsection{Saving performance of the sample households}

Household savings is average value being deposited monthly at the time of survey by households. Households usually save from their earnings for consumption smoothing purposes throughout their life time, accumulation of wealth, and for contingency purposes in case of risk and uncertainty. The results revealed that the mean monthly saving amount of the total sample household heads was found to be 968.83 birr with standard deviation of 01805.55 . Minimum and maximum saving amount of the total sample household heads was about 0 and 10000 respectively.

Among the sampled households, about $89.34 \%$ perceived saving positively and the rest perceived it either negatively or indifferent.

From the sampled households, about 53.23\% were from the business areas where business activities are relatively higher in the city. The rest were from relatively low business areas.

\subsubsection{Sex and age distribution}

The mean family size of the households was about 4.62 individuals with a standard deviation of 2.02 and minimum of 1 and a maximum of 14 household members. The mean age of the households was reasonably quite high and it was 41.49 years with a standard deviation of 10.79 and minimum of 20 and a maximum of 70 years household members. As shown in table 6, of the surveyed households, $52.48 \%$ were female respondents while $48.52 \%$ were male respondents. The data about the respondents' age showed that the average was about 42 years which ranged from 20 to 70 years.

\subsubsection{Education level of the household head}

The analyzed survey data revealed that, about $85.25 \%$ of the respondents have attended their formal education (primary, secondary, and tertiary) and the rest were either illiterate or had religious education. On average respondents education level is 9.55 grades with standard deviation of 5.5.

\subsubsection{Socioeconomic characteristics}

\subsubsection{Household income}

The most difficulty was the query on the level of income the household earns. Most of the respondents were not willing to state their earnings and others did not really know their average monthly income. But appropriate emphasis was given in the training session to this part and the enumerators were able to come up with a fair estimate of households' average monthly paycheck, taking average monthly expenditure as a cross checking mechanism.

\subsubsection{Household expenditure}

In line with this, the average monthly expenditure of the sampled households was about 2941 birr. Among different expenditure items of the households; like food, electricity, water, transport, medical, etc., food expenditure takes the lion's share as usually witnessed in developing economies.

\subsubsection{Types of employment}

Concerning the employment structure of the respondents, $30.69 \%$ of the respondents were employed in the formal sector for salary, $21.45 \%$ run their own businesses, $19.31 \%$ were housewives and students, and the rest of the respondents were unemployed, and retired. The survey result also showed that $71.29 \%$ households were living in their own house.

\subsubsection{Institutional Factors}

4.1.4.1. Credit used

According to the sample survey result the mean of credit used by the sample households was about birr 529.85 . About $74 \%$ of the sample households, during the survey, reported that they used to have annual investment plans but the rest reported that they did not have.

\subsubsection{Opinion towards the existing bank interest rates}

Respondents were asked to report their opinion towards the existing bank interest rates on savings. The result indicated that about $63 \%$ of them perceived positively and it is a big deal and the rest were in different. In here, religion was not considered by the sample respondents an issue regarding whether to save or not in banks due to interest rates. Because banks, these days, are promoting and giving interest-free saving services in Dire Dawa city. 


\subsubsection{Level of saving practice in the household}

Among the households who had practiced saving, 57\% of them used in modern type of saving method in which they take account of their money to save in private and governmental banks. This bank offers different kind of services to the societies that initiate and appreciate them to save as much as possible. Abound with the service that banks provide to the society is regarding to money transition and deposit that related with the current market system and households earning. The competition among the private banks raises the value of saving amongst the household by expanding branches and used different technologies that benchmark their sub branches. Beside to this, the government plays various roles to accomplish the five years plan that on the subject of investment and development in the country. One of the known systems that the government experienced to save money is selling bond to dweller until the plan get done.

\subsection{Econometric Model Results}

Data exploration is an important preliminary step before estimation is done. The precision of estimating the coefficients of variables is reduced by the existence of multicolliniarity between variables that is if the explanatory variables are highly correlated it is difficult to distinguish the effects of one single explanatory variable on the dependent variable (Maddala, 1992) and (Gujarati, 1998) has established a rule of thumb, if VIF of a variable exceeds 10, that variable is said to be highly collinear. Accordingly, the VIF result shows that the data had no serious problem of multicollinearity.

Table 13: Maximum likelihood estimates of the Tobit model

\begin{tabular}{lccccc}
\hline Explanatory variables & \multicolumn{3}{c}{ Tobit } & \multicolumn{2}{c}{ Marginal Effects } \\
\cline { 2 - 6 } & Coeff. & Standard & p-value & Coeff. & p-value \\
\hline Annual income of the household & $0.54 * * *$ & 0.27 & 0.000 & $0.48^{* * *}$ & 0.000 \\
Age of the household & -6.43 & 6.76 & 0.354 & -5.72 & 0.352 \\
Family size of the household & -26.01 & 41.54 & 0.539 & -23.13 & 0.538 \\
Education level of the household & $168.23^{* *}$ & 76.49 & 0.032 & $149.59^{* *}$ & 0.029 \\
Sex of the household head & -184.55 & 127.93 & 0.161 & -164.64 & 0.158 \\
Credit use of the household & $307.79^{* *}$ & 136.55 & 0.028 & $271.31^{* *}$ & 0.026 \\
Annual investment of the household & -140.18 & 200.70 & 0.495 & -126.04 & 0.493 \\
Annual expenditure of the household & $-0.25 * * *$ & 0.06 & 0.000 & $-0.22^{* * *}$ & 0.000 \\
Employed in Gov't Org. & 9.95 & 127.86 & 0.941 & 8.85 & 0.941 \\
Employed in Non Gov't Org. & 201.83 & 227.20 & 0.407 & 183.77 & 0.405 \\
Self-employed & $431.99^{* * *}$ & 198.25 & 0.008 & $381.34 * * *$ & 0.007 \\
Unemployed & -370.47 & 259.06 & 0.143 & -308.96 & 0.14 \\
Saving perception of the household & 248.10 & 364.16 & 0.503 & 211.43 & 0.502 \\
Location of business area & $258.69^{*}$ & 133.39 & 0.058 & $228.99^{*}$ & 0.055 \\
The perception of interest rate & $444.79^{* * *}$ & 156.50 & 0.006 & $383.95 * * *$ & 0.005 \\
House ownership & 334.42 & 157.65 & 0.125 & 295.09 & 0.114 \\
Constant & $-1167.78^{* *}$ & 431.91 & 0.009 & & \\
\hline Source: & & & & & \\
\hline
\end{tabular}

Source: computed from surveyed data, 2014

$* * *, * *$ and $*$ means significant at the $1 \%, 5 \%$ and $10 \%$ probability levels, respectively.

\section{CONCLUSION}

Though the theory of saving is yet to be conclusive on the determinants of saving from this study, the econometrics model result shows that out of 16 explanatory variables which were considered in the analysis 7 variables were found to be significantly influence the saving amounts of the sample households. These are; annual income of household head, education level, credit use of the household, self-employed, location of business area and the perception of interest rate positively influenced the saving amounts of the urban households in Dire Dawa City, while annual expenditure of the household negatively influence household saving. These factors therefore have to be considered in designing strategies aimed at improving the saving of the society in the study area.

\section{REFERENCE}

Besley, T. (2005). Saving credit and insurance. Handbook of development economics, 3: 2123-2207.

CSA (Central Statistical Agency), (2007). FDRE General Country Data.

Deaton, A. S., (2005). Franco Modigliani and the Life Cycle Theory of Consumption. Banca Nazionale del Lavoro Quarterly Review.

Friedman, M. (1957). A theory of the consumption function, Princeton University press, New Jersey.

Girma,T., Belay, K., Bezabih, E. and Jema, H. (2013). "Determinants of rural household savings in Ethiopia:The case of East Hararghe zone, Oromia regional state". Journal of Economics and Sustainable Development, 4 
(3).

Gujarati, D.N. (1998). Basic Econometrics.4 $4^{\text {th }}$ edition. Mc Graw-hill, Inc.,New York.

Gujarati, D.N., (2007). Basic Econometrics. $4^{\text {th }}$ edition. Mc Graw-hill, Inc.,New York.

Maddala, G.S. (1992). Limitted dependent and qualitative variables in econometrics, Cambridge University press, New York.

Maddala, G.S., (2005). Introduction to Econometrics. 3rd Edition John Wiley \& Sons (Asia)

pte. Ltd, Singapore

Marioa, B. Obwona and Jhon. (1998). Household saving in developing economics. African review of money finance and banking,No (1):pp 25-39.

MOFED (2012). Macroeconomic Developments in Ethiopia. An interim report on poverty analysis study (2010/2011). Addis Ababa, Ethiopia.

Obwona, M.B. and Ssentamu, J. (1996). Nature and determinants of domestic savings in Uganda, EPRC Research Series No. 3.

Tobin, J. (1958). Estimation of relationships for limited dependent variables. Econometrical, 26, 24-36.

Rogg, C., (2006). Asset Portfolios in Africa Evidence from Rural Ethiopia. UNU-WIDER,

Centre for the Study of African Economies, University of Oxford. Department for International Development (UK). Research Paper No. 2006/145.

First Author Meron Hailu. The author was born in Dire Dawa, Eastern Ethiopia, on June 7, 1988. She attended her primary and high school education in Biserate Geberiel and Dire Dawa comprehensive secondary schools respectively. After completion of her secondary education in 2007, she joined Haramaya University and graduated with BSc Degree Agricultural Eonomics in 2009. She again joined School of Graduate Studies of Haramaya University in 2010, to pursue her Masters study in Agricultural Economics.

Second Author Endrias Geta. The author was born in Kindo Koysha woreda, Wolaita zone, in a rural family in 1970. He completed his primary education in Oydu Chama primary school located in the nearby village and junior secondary school in Boloso Ambe junior secondary school. He attended high school education at Areka Senior Secondary school (1986-1989). He joined Alemaya University of agriculture (now Haramaya University) in September 1990 and graduated with B.Sc. degree in agricultural economics in July 1994.

After his graduation, he worked for SOS-Sahel Koysha integrated Rural Development Project (1995-1996). He then transferred to Areka Agricultural Research Center of Southern Nations, Nationalities, and Peoples' Region as a junior research in October 1996 and served there until he joined Alemaya University for his postgraduate study in September 2001. After graduating in Agricultural Economics in Masters and PhD, he becomes research advisor for Masters Student and researcher for other agricultural institution. 